\title{
The Government's Legal Standing in Build Operate and Transfer Contract
}

\author{
Sarah Selfina Kuahaty* Anwar Borahima Anshori Ilyas Nurfaidah Said \\ Faculty of Law, Hasanuddin University, South Sulawesi, Indonesia
}

\begin{abstract}
The paper analyzes the government's legal standing in build operate and transfer contract. This research is a normative-legal research. The research approach uses the statutory and conceptual approaches. The results show that the government action is an action carried out by governmental or state administration organs which are intended to have legal consequences in the field of government or State administration. In doing government actions, the government is a legal subject as the holder of rights and obligations. Therefore, as a legal subject, the government action can be carried out in both public and private law. The position of the government in civil law relatedness is not different from a person or private legal entity as a service provider, so that an equal position in this agreement results in the law that both the government and the cooperation partner can become parties in the civil dispute, so that can realize an equal justice.
\end{abstract}

Keywords: Build Operate and Transfer; Contract; Government

DOI: $10.7176 / J L P G / 88-13$

Publication date: August $31^{\text {st }} 2019$

\section{Introduction}

The government has a duty in the administration of State for the benefit of communities, by fulfilling the various basic needs of citizens. The duty is a demand from the development of the concept of the rule of law which is not only as a night watchman (nachtwachterstaat) to watch order and peace but more to the concept of a welfare State. In a legal approach, the welfare State is a translation of the term "sociale rechtsstaat" or called "sociale democratische rechtsstaat". ${ }^{1}$ In the concept of sociale rechtsstaat, the government is encouraged to advance public welfare.

Certainly, the formulation of the State's objective as mentioned has a similarity with the objectives expected from the concept of sociale rechtsstaat. In order to achieve shared-prosperity, the government has a dual position that must be conducted at the same time. Both types of government position are related to one another. First, the government as ruler in its position has the authority to make rules that must be obeyed by the peoples so that the order can be realized in reality. Second, the Government as a public servant is obliged in managing, organizing, and serving all the affairs and interests of the community. The government as a public servant is in accordance with the nature of the concept of sociale rechtsstaat in the form of "the rights to receive". ${ }^{2}$ The concept of the government as a public servant and the rights to receive in the current context is more directed at public services that must be done by the government for the benefit of the community.

As a public servant, a duty of the government is to provide adequate infrastructure. Infrastructure development certainly requires a lot of cost and budget therefore sometimes the issue of financing is an obstacle to obstructing or hindering the development of infrastructure. Thus, the government can establish cooperative relations with third parties; a cooperative relationship that benefits the government in providing infrastructure without spending a lot of budget is cooperation with partners in the form of a Build Operate and Transfer (BOT) contract.

Based on Government Regulation No. 27 of 2014 concerning the Management of State or Regional goods, State Gazette of the Republic of Indonesia No. 92 of 2014 (hereinafter referred to as Government Regulation No. 27 of 2014), in article 34 paragraph (1) it is affirmed that Build Operate and Transfer of State/regional goods can be implemented with various consideration:

a. Goods users need buildings and facilities for the administration of State / regional governments for the benefit of public services in the context of implementing main duties and functions; and

b. No funds available in the State/Regional Budget for the provision of concerned buildings and facilities.

Furthermore, it is regulated in article 35 paragraph (5) that "Build Operate and Transfer is carried out based on an agreement." Therefore, the legal relationship between the government and the private sector in this case the cooperation partners in the procurement of infrastructure with a model of the Build Operate and Transfer must be made in the form of a Build Operate and Transfer contract. In this regard, the Government has engaged into a contractual relationship with the private sector, in the form of a contract for the procurement of goods and

\footnotetext{
${ }^{1}$ Hotma P. Sibuea. 2010. Asas Negara Hukum, Peraturan Kebijakan, dan Asas-Asas Umum Pemerintahan Yang Baik. Jakarta: Erlangga. p. 42 .

${ }^{2}$ Philipus M. Hadjon. 2002. Pengantar Hukum Administrasi Indonesia, Gadjah Mada University Press, Yogyakarta, p. 74.
} 
services. The contractual relationship as established by the Government is also related to the obligation to provide, build and maintain public utilities. ${ }^{1}$

Simply, the contract can be described as an agreement between two or more parties that have a certain commercial value, which is subject to the provisions of civil law. ${ }^{2}$ As an agreement, in a contract the parties that bind themselves are legal subjects. What is meant by the legal subject here is the subject of civil law. If it is understood that what is meant by the parties in the contract is the subject of civil law, then related to the Build Operate and Transfer contract, the question arises whether it is possible that the government which is not usually perceived as a subject of civil law but the subject of public law can become one of the parties in the Build Operate and Transfer contract?

\section{Method of the Research}

The research is a normative-legal research. The research approach uses the statutory and conceptual approaches. The statute approach is done by examining all laws and regulations relating to the legal issue, in this regard, researchers need to find a logical ratio of legislation. In addition to the statutory approach, a conceptual approach is also used; this approach was done by depart from the views and doctrines that have developed in the science of law. Understanding of statutory regulations and views and doctrines is the basis for developing legal arguments for the Government's position in the Build Operate and Transfer contract.

\section{Government as Subjects of Civil Law}

Legally, the government is the subject of public law, but in its duties and responsibilities, the government often also takes civil actions such as contracting. The government that can be involved in cooperating with the private sector in contractual relations is the role of the government that can be involved both as a public actor or civil actor. The government as civil actors performs civil acts (privaatrechtelijke handelingen). Government involvement in this contract shows that the government actions are classified as civil actions. With regard to civil action in the administration of government affairs, Philipus M. Hadjon argued that: ${ }^{3}$

"Even though civil action for government affairs by State administrative bodies or officials is possible, it is not impossible that various public law provisions (State administrative law) will infiltrate and influence civil law regulations. For example, several statutory provisions that specifically regulate certain procedures that must be taken in relation with civil law efforts as carried out by State administrative bodies or officials."

The government as one of the legal subjects in civil action, then the government is a legal entity. According to Apeldoorn that State, province, municipalities and so on is legal entities. It's just that the establishment was not conducted specifically, but grew historically. ${ }^{4}$ The government is considered as a legal entity, because the governments do commercial activities (acts jure gestionisi).

As a subject of civil law, the government can bind itself with third parties in this case the providers of goods or services. The rights and obligations of each party, and the procedure for implementation must be clearly regulated and set forth in a form of contract. As a representative of a public legal entity, the position of the government is no different from the position of civil legal entities in general. In this case the government is subject to civil law provisions. This was stated by F.A.M. Stroink and J.G. Steenbeek:

"Wanner openbaar lichaam-rechtspersonen aan het privaatrechtelijk rechtsverkeer deelnemen doen zij

dat niet als overheid, als gezagsorganizatie, maar nemen zij rechtens op gelijke voet met de burger deel aan dat verkeer. Deze openbare licham-rechtspersonen zijn, deelnemende aan het provaatrechtelijke rechtsverkeer, in principe op dezelfde wijze onderworpen an de rechtsmacht van de gewone rechter als de burger." 5

According to F.A.M. Stroink and J.G. Steenbeek, if a public entity is involved in the field of civil law, then the concerned public legal entity does not act as a government or as an organization of power. In the field of civil law, in this case the governments as a public legal entity are involved together with citizens (private parties) in the relatedness of law based on civil law. Public legal entities involved in legal relatedness based on civil law must be subject to the legal authority of ordinary justice as citizens. Furthermore, J.B.J.M. ten Berge argued that, "De overheid kan net als natuurlijke personen en privaatrechtelijke rechtspersonen deelnemen aan het privaatrechtelijke rechtsverkeer." In the field of civil law, for the Government can act, the government is positioned as a human and private legal entity. Civil law actions are legal actions governed by civil law. According to R.J.H.M. Huisman, "Privaatrechtelijke rechtshandelingen zijn de rechtshandelingen die worden

\footnotetext{
${ }^{1}$ Simamora Sogar Y. 2009. Hukum Perjanjian, Prinsip Hukum Kontrak Pengadaan Barang dan Jasa Oleh Pemerintah. LaksBang PRESSindo: Yogyakarta. p. 2

${ }^{2}$ Ahmadi Miru. 2011. Prinsip-prinsip perlindungan hukum bagi konsumen di Indonesia. RajaGrafindo Persada, p.53

${ }^{3}$ Philipus M. Hadjon, Op.Cit., p. 167

${ }^{4}$ L. J van Apeldoorn, Pengantar Ilmu Hukum, Noor Komala, Jakarta, 1982, p.164

${ }^{5}$ F.A.M. Stroink and J.G. Steenbeek, Inleiding in het Staats Administratiefrecht, Samson, 1993, p. 28
} 
beheerst door het privaatrecht."1

In the field of civil law, a legal relation rely on the principles of autonomy and freedom of contract (contractsvrijheid), in the sense of full independence for legal subjects to do or not do legal actions, and good intentions in various agreements (goedetrouw bij de uitvoering van overeenkomsten). Based on the principle of autonomy and freedom of contract, equality occurs between parties without one of them having a special position and force to oppose the other party. On this basis, the government can only "align" itself with a person or civil legal entity in the capacity of the government as a representative of a public legal entity and not a representative of a position in public law. It is in accordance with the argument of Aminudin Ilmar ${ }^{2}$ who states that when the government takes an action or legal action in the field of private law and then subject to the civil law regulation, then it must be explicitly stated, that the action is considered as a representative of a legal entity or a public legal entity (openbare rechtspersoon) and is no longer a representative of the position as determined under public law.

It is a fact that not all government affairs are currently carried out by official government agencies, but sometimes to achieve the objectives of the government, the government prefers to use legal institutions based on civil law with all its variations. The means of open channels in civil law provide many possibilities for policies that can be realized or carried out according to the provisions of the applicable legislation.

The government as one of the legal subjects in civil action, then the government is a legal entity. According to Apeldoorn that State, province, municipalities and so on are legal entities. Even though, the establishment was not done specifically, but grew historically. ${ }^{3}$ The government is considered as a legal entity, because the government carries out commercial activities (acts jure gestionisi).

\section{The Government's Position in the Build Operate and Transfer Contract}

In order to improve public services, the local government is given the authority to manage regional goods that purchased, obtained at the expense of the Regional Budget or sourced from other as stipulated in Government Regulation No. 27 of 2014. One of the regional goods that are necessary for utilized is land. In this effort, good planning is needed, including financing planning. Sometimes the local government is constrained because of the limited budget; then to overcome this, the government cooperates with other parties as cooperation partners. The cooperative relationship between the government and partners causes the government to take civil legal action, as a subject of civil law as stated earlier.

A form of contract that can be used by the government in the process of utilizing land for procurement of construction services is the Build Operate and Transfer (BOT) contract. The concept of BOT became widely known around 1985 in Turkey, as the concept of privatization of Prime Minister Turgut Ozal. This concept is also known as "Turgut's Formula". On May 11, 1987 cooperation was signed between Kumagai Kigumi from Japan and Yuksel Insaat from Turkey for the construction and management of a dam on Syehan River. This project is worth 231.5 million USD. The period of construction is 5 years and the management is 26 years, and then submitted to the Turkish government (Turkish Electronical Authority). This cooperation agreement is the beginning of the concept of BOT in infrastructure projects in Turkey which is then widely followed by developing countries, including Indonesia. ${ }^{4}$

BOT in Article 1 No. 13 of the Government Regulation No. 6 of 2006 jo Article 1 NO. 22 of the Regulation of Domestic Minister No. 17 of 2007 jo Article 1 No. 36 of the Regulation of Domestic Minister No. 19 of 2016 is the utilization of regional goods in the form of land by other parties by means of constructing buildings and/or infrastructure and their facilities, then utilize other parties within a certain agreed period of time, to subsequently be handed back land and buildings and/or facilities after the expiry of the period. The meaning of BOT is also found in the Regulation of Domestic Minister No. 22 of 2009 concerning Technical Guidelines on Regional Cooperation Procedures, Appendix II, it explains the Build Operate and Transfer contracts in which legal entities are responsible to build infrastructure/facilities, including financing and after completion of construction then infrastructure/facilities is transferred to the Local Government, then the Local Government gives back to the legal entity to be managed for a certain time to return the investment capital and obtain a reasonable profit. Aminuddin Ilmar argued that the agreement of Build Operate and Transfer is a form of development project financing which is collaboration between the parties where an object is built, managed or operationalized for the specified period of time agreed and in the end the agreement is submitted to the original owner. ${ }^{5}$

Actually, the Build Operate and Transfer contract is a pattern of cooperation between land and land owners including the government, with the cooperation partners as investors who will build a building or other

\footnotetext{
${ }^{1}$ Philipus M. Hadjon, Op. cit. p.168

${ }^{2}$ Aminuddin Ilmar. 2004. Hukum Penanaman Modal di Indonesia. Kencana: Jakarta. p. 101

${ }^{3}$ L. J van Apeldoorn, Op.Cit, p.16

${ }^{4}$ Budi Santoso. 2008. Aspek Hukum Pembiayaan Proyek Infrastruktur Dengan Model BOT (Built, Operate and Transfer). Genta Press: Yogyakarta. p. 13

${ }^{5}$ Aminuddin Ilmar. Op.Cit. p. 62
} 
construction as agreed on the land. It can be seen that the activities as performed by investors from build facilities as desired by the land owner, this is meant by $B$ (build). After the construction of the facility is completed, the investor is given the right to manage and collect the proceeds from the facility for a certain period of time, this is meant by $O$ (operate). After the operation or concession period is completed, the facility is returned to the construction service user or land owner, this is meant by $T$ (transfer), so it is called a contract of Built, Operate and Transfer. ${ }^{1}$

State or regional-owned goods BOT can be implemented with the conditions if the goods user wants buildings and facilities for the implementation of the main tasks and functions of the central and local government for public service purposes, but there are no funds available in the State or Regional Budget. The procurement of buildings and facilities as performed by the Goods Manager ${ }^{2}$ after obtaining approval from the Governor or Regent or Mayor, and the cooperation partners as established for a certain period of time. In operating period, the cooperation partner must pay contributions to the State or regional general cash account each year, in which the amount is determined based on the results of the calculation of the team established by the competent official i.e the Contribution Assessment Team, ${ }^{3}$ by considering that the regional-owned goods have not been utilized and have not been optimized, in order efficiency and effectiveness as well as increasing regional revenue and supporting the development and community programs of the regional government.

As part of the contract of procurement, then in the process of procurement of goods or services in the form of a Build Operate and Transfer contract is a form of agreement that has its own character, the contract give a distinct feature in the realm of private law but cannot be denied that in the contract there is a public feature. The public law as in such contract is a distinguishing character from commercial contracts in general. This distinctive character by the government in addition to relating to the formation and implementation of contracts, it is also related to the procedures in its procurement. The principles and norms in private law apply side by side with the principles and norms in public law. Therefore, the management of regional-owned goods as in BOT model is not enough if it is only supported by civil provisions, especially contract legal norms, it also needs public rules. In accordance with Presidential Decree No. 16 of 2018, the government as a party to the contract has the authority inherent in it, the government authority to do action must always be based on the laws and regulations that have been established. Authority can be obtained by attribution, delegation and mandate. Attribution is the authority inherent to a position, delegation is the transfer of authority to other government organs, and the mandate is the delegation of authority from superiors to subordinates.

In legal actions as a legal subject in a commercial contract with a private sector, it is necessary to consider who is the subject representing the government, then whether the subject or official representing the government in signing an agreement with the private party has fulfilled the State administrative law procedures. In theory, the State administrative law explained that any agreement made by the government within the scope of the agreement is always preceded by a Decree of State Administration to do an ordinary or other civil law action. By the decree, a civil agreement is made. ${ }^{4}$

The feature of public law in BOTs contracts related to positions that emerge from public authority, then the legal relation as created between the government and cooperation partners in procurement procedures begins also with a public act by the government, namely the establishment of the Selection Working Group, where the appointment of the Working Group is established with a State administrative decisions in the form of regional government decisions as one of the government authority to create decisions.

Local government decisions related to the establishment of the Selection Working Group or based on the provisions of the procurement of goods or services previously known as the Procurement Committee, i.e Mayor Decree of Makassar No. 686/Kep/050/2007 dated March 27, 2007 regarding the Establishment of Field Revitalization Tender Committee of Karebosi, and also the Governor Decree of Maluku No. 43/Kep/I/2010 regarding the Establishment of a Procurement Committee for the Development and Operation of an Integrated Shopping Center on the Regional Government-owned land of Maluku. The establishment of the Election Working Group with a State administrative decision, the Selection Working Group in conducts the duties and responsibilities given to it, it is based on its public authority, so that the actions taken by the Selection Working Group are based on their position.

After going through the preparatory procedure up to the selection stage as conducted by the Selection Working Group through a tender procedure, the Governor or Regent or Mayor as the holder of the authority to manage regional goods determines the winner of the tender. Some examples of the determination of regional

\footnotetext{
${ }^{1}$ Nazarkhan Yasin. 2006. Mengenal Kontrak Konstruksi di Indonesia. Gramedia Pustaka Utama: Jakarta. p.76

${ }^{2}$ Goods manager in Article 1 No. 3 of the Regulation of Government No. 27 of 2014 is the official authorized and responsible for setting policies and guidelines as well as managing State or regional goods. The Minister of Finance as the general treasurer is the manager of State goods (see Article 4 paragraph (1)), and the regional secretary is the manager of regional goods (see Article 5 paragraph (3)).

${ }^{3}$ See article 36 paragraph (3) point $a$, the Regulation of Government No. 27 of 2014

${ }^{4}$ Iwan E. Joesoef. 2006. Perjanjian Pengusahaan Jalan Tol (Ppjt) Sebagai Kontrak Bisnis Berdimensi Publik Antara Pemerintah Dengan Investor (Swasta) Dalam Proyek Infrastruktur. Jakarta. Badan Penerbit Fakultas Hukum Universitas Indonesia. p. 29
} 
heads related to the winner of bidder are the determination of Mayor Decree of Makassar No. 686/Kop105012007 dated August, 72007 regarding the determination of PT. Tosan Permai Lestari as the winner of tender for Field Revitalization of Karebosi Makassar. the Governor Decree of Maluku No. 281 of 2010 regarding the determination of the winner of tender for the Development and Operation of an Integrated Shopping Center on the regional government-owned Land of Maluku. The determination of the winner of tender by BOT model as determined by the State administration decision is the implementation of article 288 of the Regulation of Domestic Affairs Minister No. 19 of 2016 which regulates that "the results of the selection of BOT partners are determined by the Governor or Regent or Mayor."

Broadly speaking, the procedure of procurement is divided into 3 (three) stages; the first; preparation stage, among other planning, establish a working group of procurement, determine a procurement system, preparing procurement schedule, preparing a technical specification and the estimated price (HPS - Harga Perkiraan Sendiri), and preparing procurement documents; the second is signing contract and the third is implementation stage. In preparation stage is a stage where the feature of public law dominates its implementation, but when it comes to the contract signing stage which begins with the pre-contract process, then when the feature of private law dominates its implementation. When it arrives at this stage, the State Administration Decree made by the government in relation to the contract of procurement of goods and services is made as the beginning of the contract or pre-contract formation and becomes the basis for the formation of the contract. The substance of the State Administrative decree as a pre-contract then merges into the realm of civil law as a civil law action.

The involvement of government with the cooperation partners is a relation of civil law and it is a legal choice in the framework of implementing cooperation agreements in BOT model. Utilization of these civil legal instruments is important for the government in public service functions. When the government doing a cooperation agreement with a private cooperation partner, it must be judged that the government must submit to and obey the provisions of civil law, this can be seen in the contract clauses that have been agreed between the government and the cooperation partners. In this situation, all legal consequences applied as arise due to the established relation and consequences of the application of legal principles and rules in the field of civil law, both formal and material.

When the government acts in the realm of civil law and subject to the civil law rules, then the government acts as a representative of the legal entity. Therefore, giving legal consequences that the government' position in the relatedness of civil law is not different from a person or private legal entity, does not have a special position, the government has an equal position with other parties in the agreement made. Therefore, the government can be a party to a civil dispute with the same position as a person or a legal entity (equality before the law) in general justice.

\section{Conclusion}

Government action is an action carried out by governmental or State administration organs which are intended to have legal consequences in the field of government or State administration. In doing government actions, the government is a legal subject as the holder of rights and obligations. Therefore, as a legal subject, the government action can be carried out in both public and private law. In this situation, the government appears in 2 (two) institutions, both position institution in the field of public- or civil laws, the position of government in the field of private law is a representative of the legal entity, so that both the government and the cooperation partner has a balanced position, therefore both the government and the cooperation partner in the implementation of construction procurement work by using BOT model have an equal position. The position of the government in civil law relatedness is not different from a person or private legal entity as a service provider, so that an equal position in this agreement results in the law that both the government and the cooperation partner can become parties in the civil dispute, so that can realize an equal justice.

\section{References}

Ahmadi Miru. 2011. Prinsip-prinsip perlindungan hukum bagi konsumen di Indonesia. RajaGrafindo Persada.

Aminuddin Ilmar. 2004. Hukum Penanaman Modal di Indonesia. Kencana: Jakarta.

Budi Santoso. 2008. Aspek Hukum Pembiayaan Proyek Infrastruktur Dengan Model BOT (Built, Operate and Transfer). Genta Press: Yogyakarta.

F.A.M. Stroink and J.G. Steenbeek, Inleiding in het Staats Administratiefrecht, Samson, 1993.

Hotma P. Sibuea. 2010. Asas Negara Hukum, Peraturan Kebijakan, dan Asas-Asas Umum Pemerintahan Yang Baik. Jakarta: Erlangga.

Iwan E. Joesoef. 2006. Perjanjian Pengusahaan Jalan Tol (Ppjt) Sebagai Kontrak Bisnis Berdimensi Publik Antara Pemerintah Dengan Investor (Swasta) Dalam Proyek Infrastruktur. Jakarta. Badan Penerbit Fakultas Hukum Universitas Indonesia.

L. J van Apeldoorn, Pengantar Ilmu Hukum, Noor Komala, Jakarta, 1982.

Nazarkhan Yasin. 2006. Mengenal Kontrak Konstruksi di Indonesia. Gramedia Pustaka Utama: Jakarta. 
Philipus M. Hadjon. 2002. Pengantar Hukum Administrasi Indonesia, Gadjah Mada University Press, Yogyakarta

Rugebregt, R.V., Saleng, A., and Patittingi, F. (2016). "Government Policy in the Natural Resource Management of Local Community," Hasanuddin Law Review 2 (1), 122-129.

Simamora Sogar Y. 2009. Hukum Perjanjian, Prinsip Hukum Kontrak Pengadaan Barang dan Jasa Oleh Pemerintah. LaksBang PRESSindo: Yogyakarta. 